2 To (Recerving Organization)

Documentation and Records Mgmt

5 Proj/Prog/Dept/Div

Spent Nuclear Fuel Project

8 Originator Remarks

Project filing of the Fuel Basket Handling Grapple Design

Development Report and the Fuel Basket Handling Grapple Acceptance

Test Report (Production Grapples) Two Reports by MCE Englneerıng

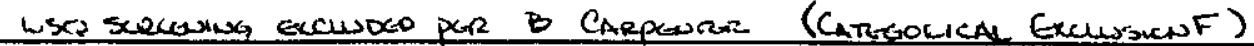

11 Recerver Remarks 11A Design Baseline Document? $\bigcirc$ Yes $O$ No

Design Development report verifies the design adcequacy per tested verification of required safety factors The acceptance test report verifies each production grapple has been proof tested as required

\begin{tabular}{l}
4 Related EDT No \\
EDT 628503 \\
\hline 7 Purchase Order No \\
00003170 \\
9 Equip /Component No
\end{tabular}

DES-12-1 (001 to009)

10 System/8/dg /Facility

$\mathrm{SNF} / \mathrm{KE} \& \mathrm{KW} / 100 \mathrm{~K}$

12 Major Assm Dwg No

Vendor MCE DES-12-1

13 Permit/Permit Application No

$\mathrm{N} / \mathrm{A}$

14 Required Response Date

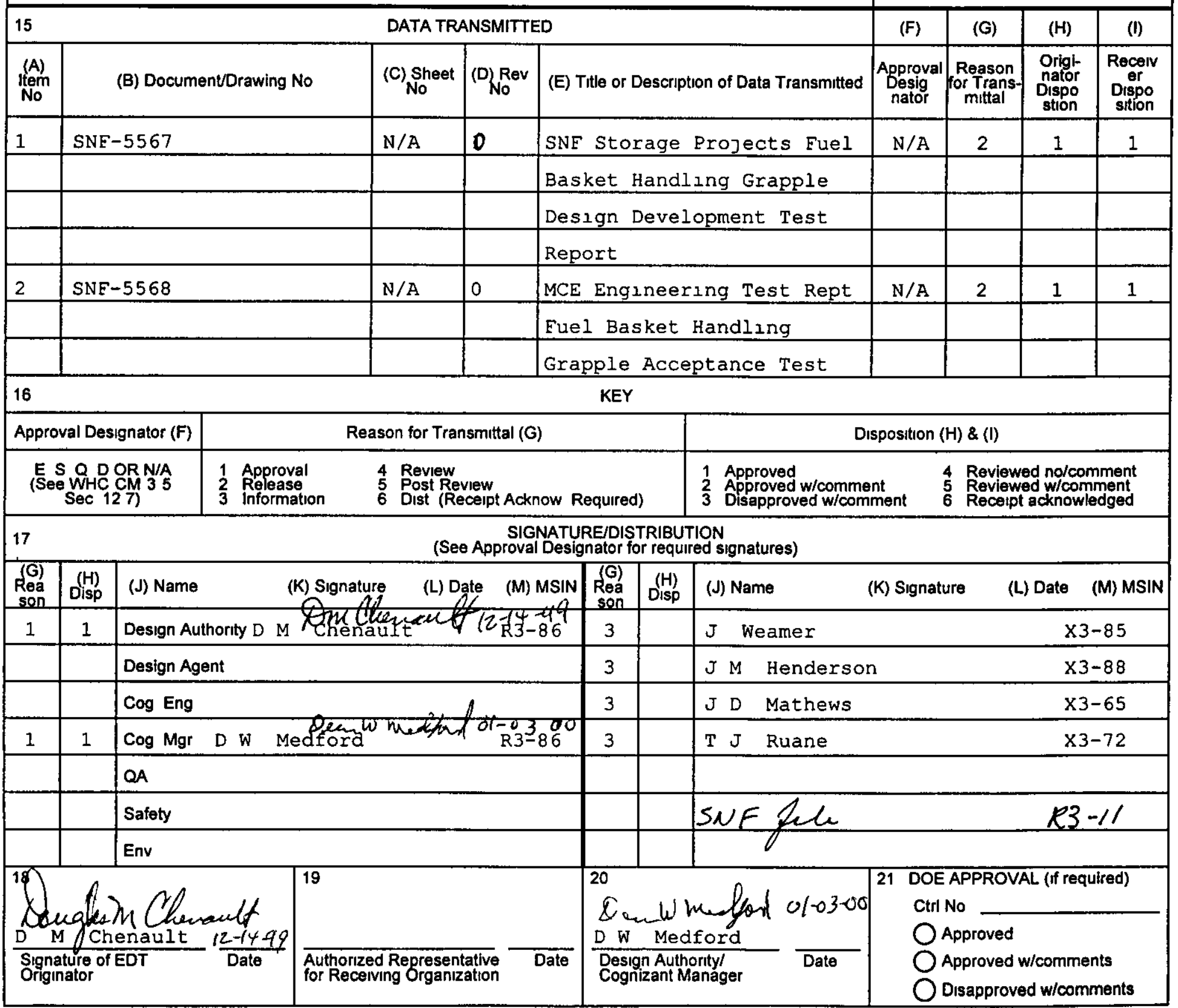




\section{MCO ENGINEERING TEST REPORT FUEL BASKET HANDLING GRAPPLE ACCEPTANCE TEST}

D M Chenault

Fluor Hanford Incorporated Richland WA 99352

U S Department of Energy Contract DE AC06 96RL13200

\begin{tabular}{|c|c|}
\hline $\mathrm{EDT} / \mathrm{ECN} \quad 628503$ & $\begin{array}{l}\text { UC } 510 \\
\text { Charge Code } 105528 / \mathrm{DA} 00\end{array}$ \\
\hline Org Code YA300 & Charge Code $105528 / \mathrm{DA} 00$ \\
\hline B\&R Code EW7040000 & Total Pages 28 \\
\hline
\end{tabular}

Key Words Grapple Proof Test Basket Lift Fuel

Abstract Acceptance testing of the production SNF Fuel Basket lift grapples to the required 150 percent maximum lift load is documented herein The report shows the results affirming the proof test passage

TRADEMARK DISCLAIMER Reference herein to any specific commercial product process or service by trade name trademark manufacturer or otherwise does not necessanly constitute or imply its endorsement recommendation or favoring by the United States Government or any agency thereof or its contractors or subcontractors

Printed in the United States of Amenca To obtain copies of this document contact Document Control Services P O Box 950 Malstop H6 08 Richland WA 99352 Phone (509) 3722420 Fax (509) 376-4989
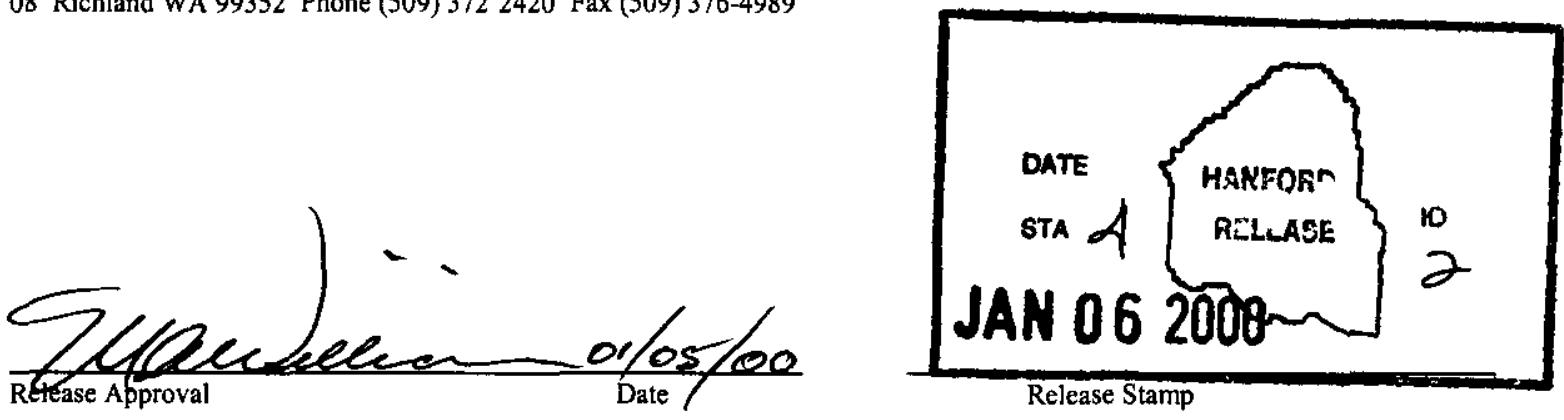

\section{Approved for Publıc Release}


May 101999

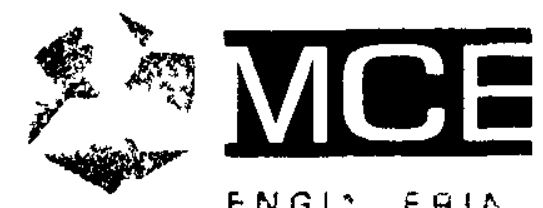

$E N G|\cdot E F| A$

Mr Ron L Butler

DE\&S Hanford

PO Box 350

Richland WA 99352

Subject CONTRACT 00003170 SUBMITTALS AND NOTICE OF COMPLETION

Dear Mr Butler

Mid-Columbia Engineering, Inc (MCE Engineering) is notifying you of our completion of the grapple repair per the terms of contract 00003170 At this time we are enclosing our load test documentation for your records The reparred grapple assemblies have been delivered to the buyer s technical representative Doug Chenault per the terms of the contract

I have instructed our Back Office to prepare invorcing for $\$ 1098300$ per the firm fixed price terms of the contract

Please feel free to contact me at (509) 943-6706 Ext 234 with any items requiring clarification

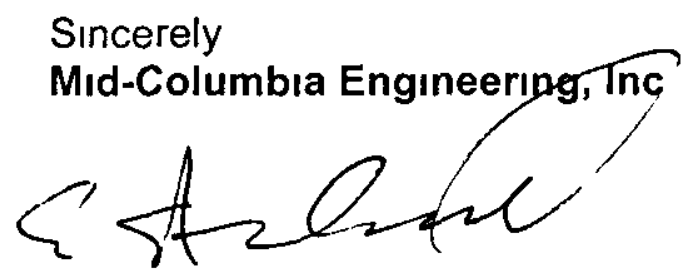

Erıc Straalsund

General Manager

EKS/Jmp 063L-99-EKS 
SNF-5568, Rev 0

MCE Engineering Test Report

Fuel Basket Handlıng Grapple

Acceptance Test

Job No PO 3170

Prepared by

Concurred by

Approved by

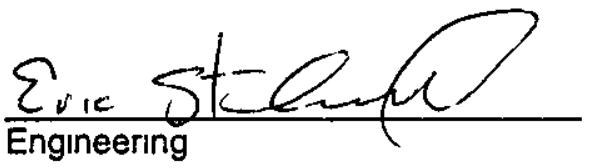

Uct

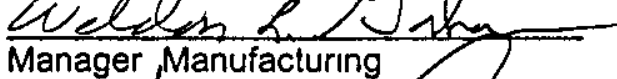

Manager Manufacturing

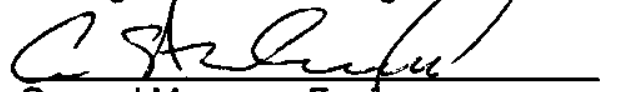

General Manager Engikeering $\frac{5 / 10 / 99}{\text { Date }}$

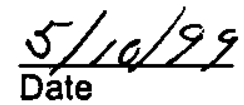

$5 / 10 / 9$ 


\section{SNF-5568, Rev 0}

\section{Introduction}

This report provides the results of an acceptance test that was completed on nine grapple assemblies for handling MCO fuel baskets for the SNF Project These grapple assemblies were fabricated to MCE Drawing Number DES 121 REV 1 Specifically testing was formed to evaluate the load acceptance of a new material (Inconel 718) being used on the actuator shaft and engagement balls This report summarizes the results of the test and provides an initial evaluation of the test results NDE testing which was performed following completion of the load test is also described along with the results of this test

\section{Test Objective}

The primary objective of this test was to confirm the load ratıng of the grapple per applicable requirements of ANSI 146 American National Standard For Radıoactive Materials Special Lifting Devices for Shipping Containers Weighing 10000 pounds $(4500 \mathrm{~kg}$ ) or More The above

Standard requires a load test of $150 \%$ of the design load which must be held for a minimum of 10 minutes followed by a Liquid Penetrant or Magnetıc Partıcle examınation of critical areas and welds in accordance with the ANSI/ASME Boller and Pressure Vessel Code 1989 Section III Division 1 section NF 5350

\section{Basis for Testing}

The test was to be conducted using Test Procedure EP\#9 Rev 0 The completed Test Procedure along with data sheets for each grapple tested is included as Appendix A to this report The design load specified for this grapple is 3200 pounds The required test load is thus $(3200)(15)=4800$ pounds

\section{Test Description}

The test was performed using the test setup described in Appendıx A The test hardware was the prototype grapple which had been designed and fabricated by MCE Engineerıng based on a detailed design provided by the client The test fixture consists of a load reacting cylinder mechanısm which transfer load from a hydraulic cylınder through the grapple to a lower plate which is fastened to the mating portion of the grapple The loading device is a 0 to $10000 \mathrm{psig}$ double actıng Enerpac hydraulic cylınder Loading was monitored by a calibrated 0 to $10000 \mathrm{psig}$ Ashcroft gage Prior to the test the Ashcroft gage was calıbrated by Bellhaven Calibration of the Ashcroft gauge found the gauge to read in error by nominally $25 \%$ low The five point calibration curve was used to correct readings taken from the gauge to actual pressure and corresponding load However during testıng the correction calculation was incorrectly applied and the test pressure and loads were significantly over applied This resulted in testing each of the test articles at loads much greater than the target load of 4800 pounds See Table 41 for actual test loads Appendix $B$ of this report includes copies of the Ashcroft calibration data and calculations

The test was conducted at MCE Engineerıng s fabrication division G\&M Manufacturing The test was witnessed by the client engineering and quality assurance representatives 
SNF-5568, Rev 0

Table 41 Summary of Test Conditions

\begin{tabular}{|l|c|c|c|l|}
\hline Grapple ID & $\begin{array}{l}\text { Displayed } \\
\text { Pressure }\end{array}$ & $\begin{array}{l}\text { Corrected } \\
\text { Pressure }\end{array}$ & Calculated Load & Comments \\
\hline $\begin{array}{l}\text { H 1 82864 010 001 } \\
\text { Backbore Design }\end{array}$ & 1650 & 236090 & 1111985 & Held load 10 Minutes \\
\hline H 1 82864 010 002 & 1700 & 242542 & 1142372 & Held load Minutes \\
\hline DES 121010 004 & 1650 & 236090 & 1111985 & Held load 10 minutes \\
\hline DES 121010 005 & 1650 & 236090 & 1111985 & Held load 10 minutes \\
\hline DES 121010 006 & 1650 & 236090 & 1111985 & Held load 10 minutes \\
\hline DES 121010 007 & 1600 & 229639 & 1081598 & Held load 10 minutes \\
\hline DES 12 1010 008 & 1650 & 236090 & 1111985 & Held load 10 minutes \\
\hline DES 12 1010 009 & 1700 & 242542 & 1142372 & Held load 10 minutes \\
\hline $\begin{array}{l}\text { H 1 82864 010 001 } \\
\text { Retaining Wire Design }\end{array}$ & 2807 & 385381 & 1815143 & $\begin{array}{l}\text { Load Tested to 3X } \\
\text { and 5X Load per } \\
\text { MCE EP 11 }\end{array}$ \\
\hline
\end{tabular}

\section{Test Results}

Following completion of the loading sequence the each test unit was disassembled and visually inspected for any damage Local deformation of the fuel basket receptacle interface lip was observed at the contact point with the detent balls Minor deformation of the actuator shaft/detent ball interface was also observed This local deformation of the fuel basket receptacle and actuator shaft was well withın expected lımits There was no deformation noted at the grapple housing/detent ball interface

Following testıng each actuator shaft (item 7) was lıquid penetrant inspected per ASME Section III Division 11989 and accepted per requirements of NF 5350 This examınation was performed to insure that no cracking had occurred The test indicated that no cracking had occurred The examination reports are included as Appendıx $\mathrm{C}$ to this document

\section{Conclusions}

Testıng of the MCO Basket grapple prototype at nomınally $350 \%$ of expected desıgn load indicated that the unit functioned as planned with only the expected local deformation at contact points Testıng indicates that the load capability of the grapple assembly has not been compromised as a result of changing the actuator shaft and engagement ball materials to inconel 718

From this test it is concluded that the design configuration meets or exceeds the requirements specified in ANSI N 146 for Special Lifting Devices for Shippıng Containers Weighıng 10000 Pounds $(4500 \mathrm{~kg})$ or More 
SNF-5568, Rev 0

Appendıx A

MCE Engıneerıng Procedure \#9 Rev 0

Fuel Basket Handling Grapple

Load Test Procedure and Data Sheets 
MCE Engineering Enginecring Procedure \#9

FUEL BASKET HANDLING GRAPPLE LOAD

TEST PROCEDURE

JOB NO PO M 414379, Txsk 18

Prepared by

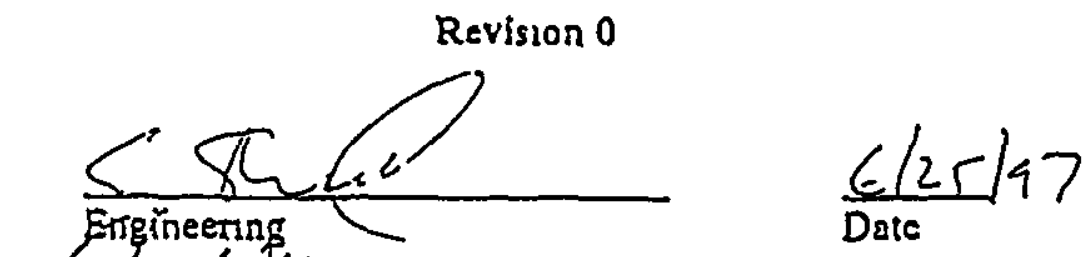

Concurred by

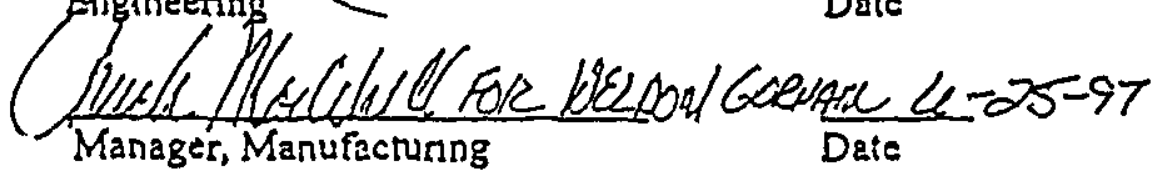

Concurred by

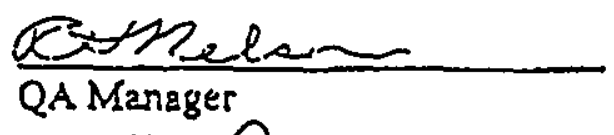

$\frac{7 / 2 / 97}{\text { Dare }}$

Approved by

Concurred by

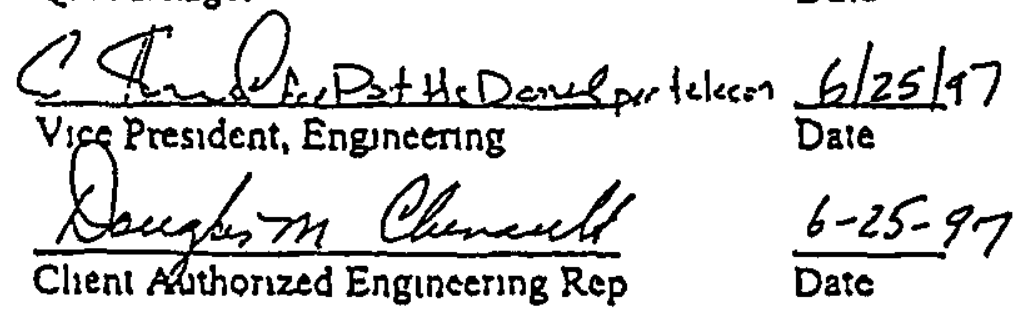


SNF-5568, Rev 0

\section{INTRODUCTION}

This document detalls load test requirements for a new grapple fixture for handling MCO fuel baskets This grapple is documented in a released MCE Engineering Drawing DES-1-1 Sheet 1 , Rev 1, and DES 1-1 Sheet 2, Rev 0 Specifically, this document defines the test objectives, acceptance criteria, and test responsibilities

\section{TEST OBJECTIVES}

The primary objective of this testing is to confirm load ratıng of the grapple per applicable requirements of ANSI 146 , "American National Standard for radioactive materials - special lifting devices for shipping contanne1s weighing 10,000 pounds (4500g) or more " ANSI N14 6 requires a load test of $150 \%$ design load, held for a minimum of 10 munutes, followed by a Liquid Penetrant or Magnetic Particle examination in accordance with the ANSI/ASMI Boiler and Pressure Code, 1989, Section III, Division 1

\section{TEST RESPONSIBILITIES}

\section{MCE Engineering (MCE)}

MCE Engineering's Engineering staff shall prepare the test procedure and conduct load testing Upon completion of the load test, MCE's Engineering staff shall document the test results in a letter report to be included with the Grapple Fabrication Data Package The Test Procedure and Test Report shall be reviewed and concurred by MCE's Quality Assurance Staff QA will NOT be required to witness testing

\section{Duke Engineering Services Hanford (DESH)}

Duke Engineering Services is the end user of the grapple DESH shall review and concur the test procedure, provide an optional witness of test activities - if desired, and review and concur the final test report Duke Engineering Services shall also provide the required Fuel Basket Receptacle Interface 


\section{Measurement Ranges and Accuracy}

The test loads specified in this procedure are nominal The test performer shall apply the nominal load and record the actual load in the data sheet The minimum increment for the pressure gauge is $100 \mathrm{psi}$ It is reasonable that the pressure can be recorded to the nearest 50 psi However, to ensure results are conservative, all readings shall be rounded down Data shall be recorded in accordance with the tolerances specified on the forms in Appendices A, B, C, D, and E Loads applied to the test fixture are derived by dividing the applied pressure by the specified effective cylinder area in retraction For the Enerpac RRH-307 cylinder used for this test the effective cylinder area in retraction is specified to be 471 square inches Thus, the corresponding pressure for a $4800(3200 * 150 \%)$ pound load is 1020 psig For this test, minmum pressure will be set to $1100 \mathrm{psig}$ or a corresponding load of not less than 5181 pounds

\section{Instrument/Equipment Calibration}

The measuring devices and the pressure gauge shall be calibrated, and documentation provided with the test report as a record

\section{TEST REPORT}

A report shall be prepared presenting the recorded data and observations using completed data sheets generated during conduct of this test procedure The report shall include a summary of the testing performed and the results of the evaluations during testing $A$ copy of all required Non Destructive Exammations shall be mcluded with the repoit

\section{CONFIGURATION CONTROL}

Pror to initiating formal test activities this test procedure shall be approved and released into MCE Engineering's document control system At the test director's and client's mutual agreement MINOR procedure changes can be implemented using red-line control Red-line mark-ups to the test procedure shall be initialed by the MCE Test Director AND the Authorized Client Engineering Representative MNOR procedure changes are changes that streamline test conduct or alter the sequence of test activities MAJOR procedure changes that alter the scope or intent of testing requires signature approval commensurate with original document release and requires a direct revision to this procedure

\section{TEST PROCEDURE}

The associated data sheets are listed in Sections 71 through 74 of this procedure 


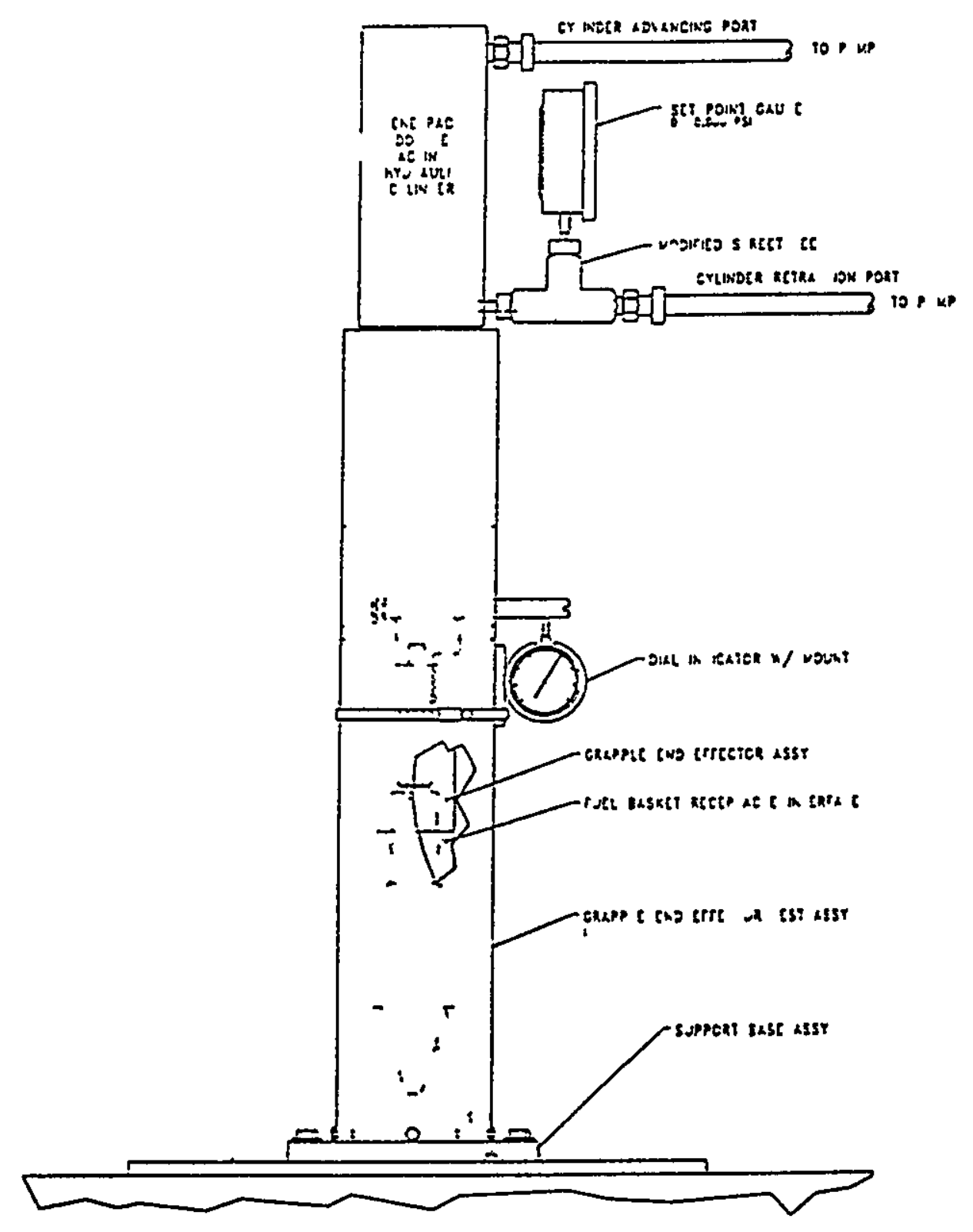

Figure 1 Test Apparatus Assembly 


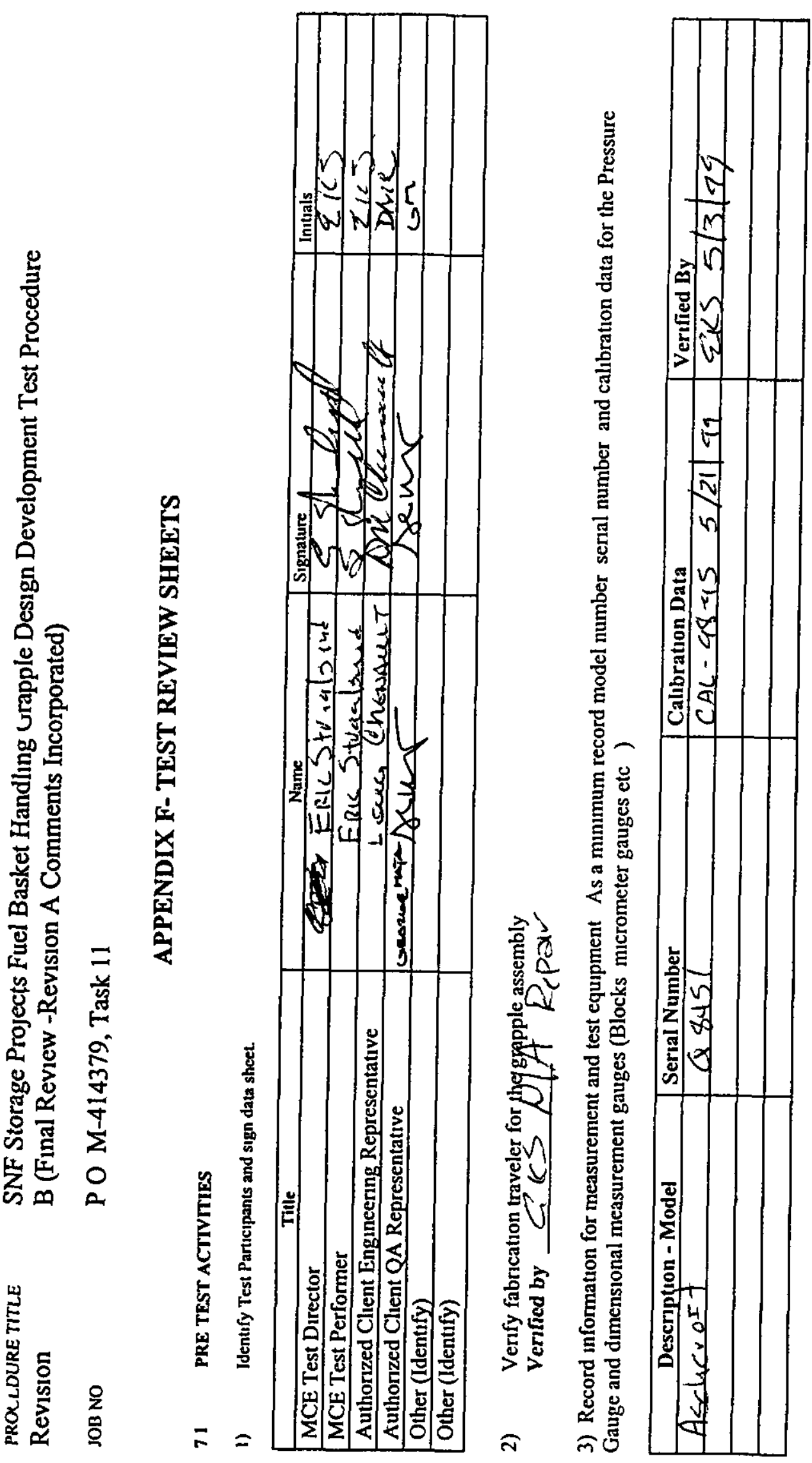


SNF-5568, Rev 0

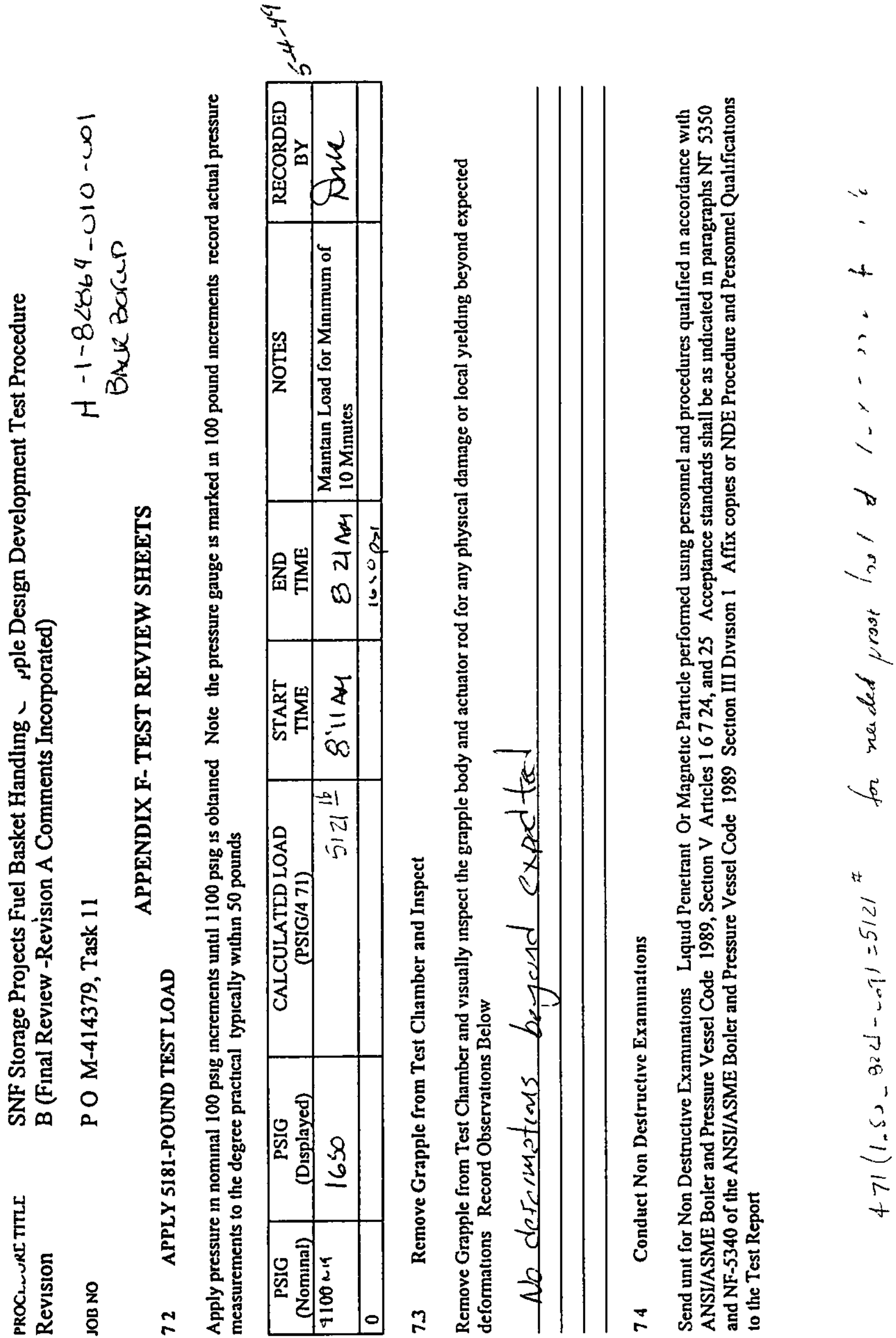




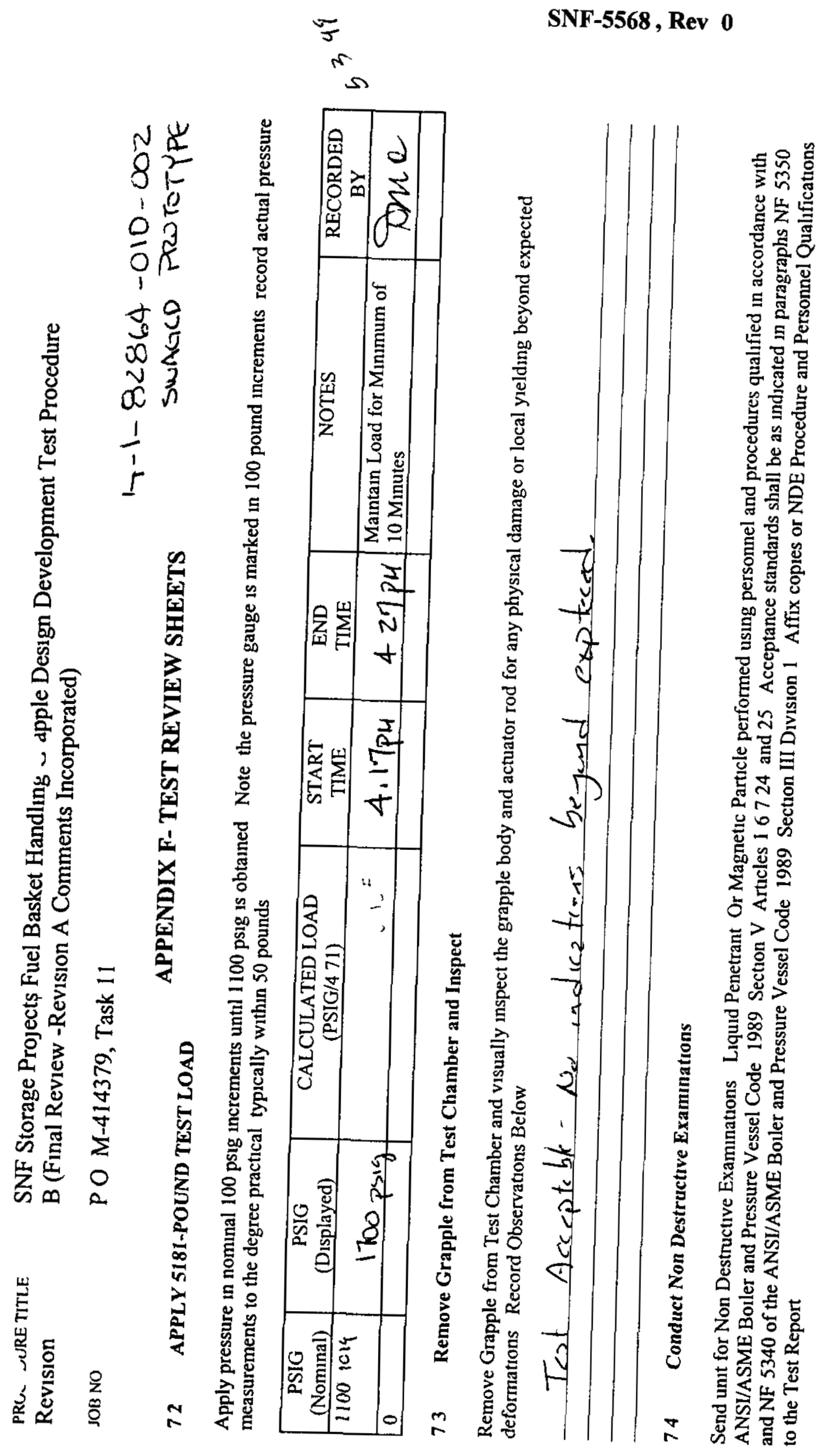

咅 


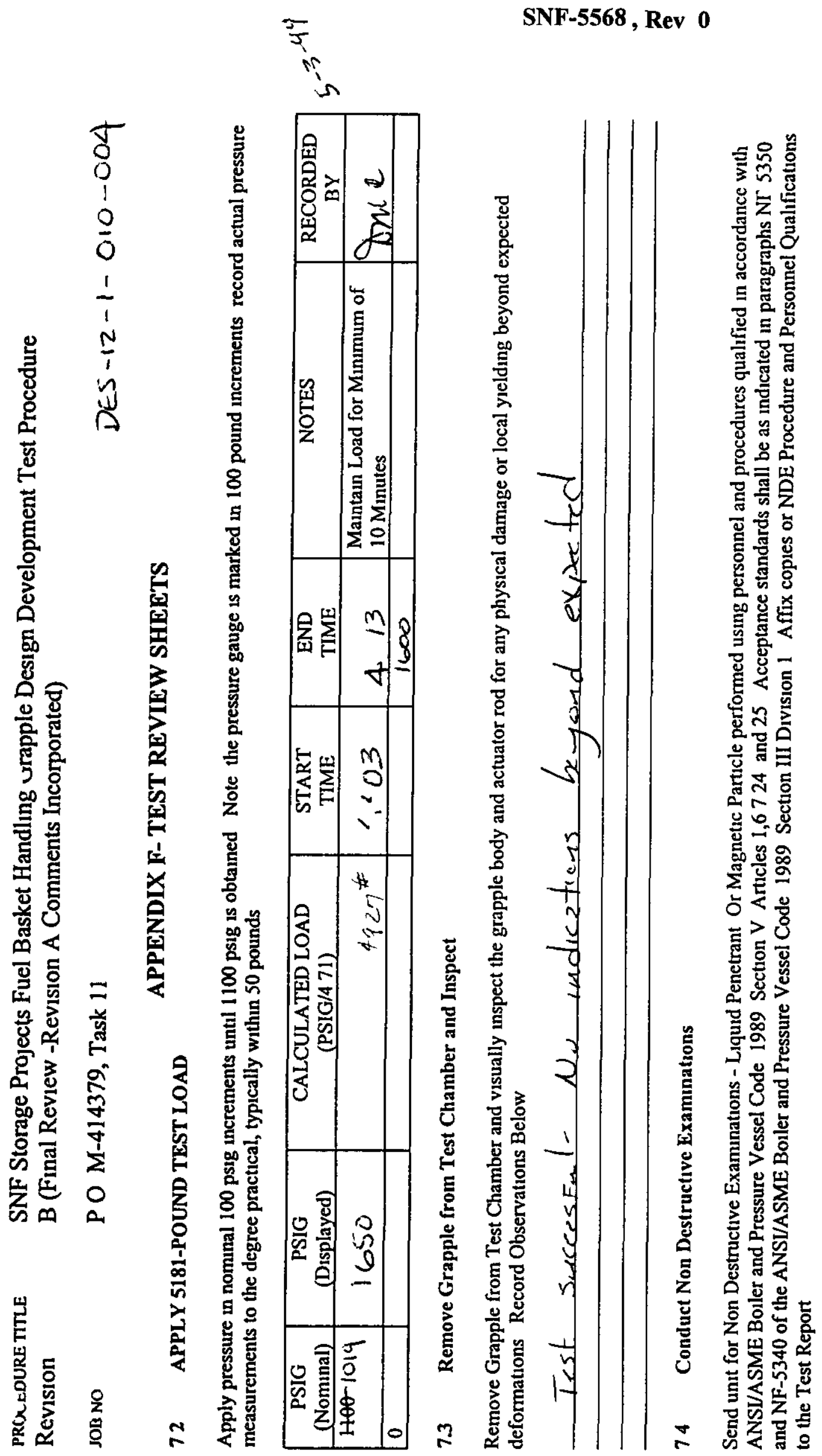




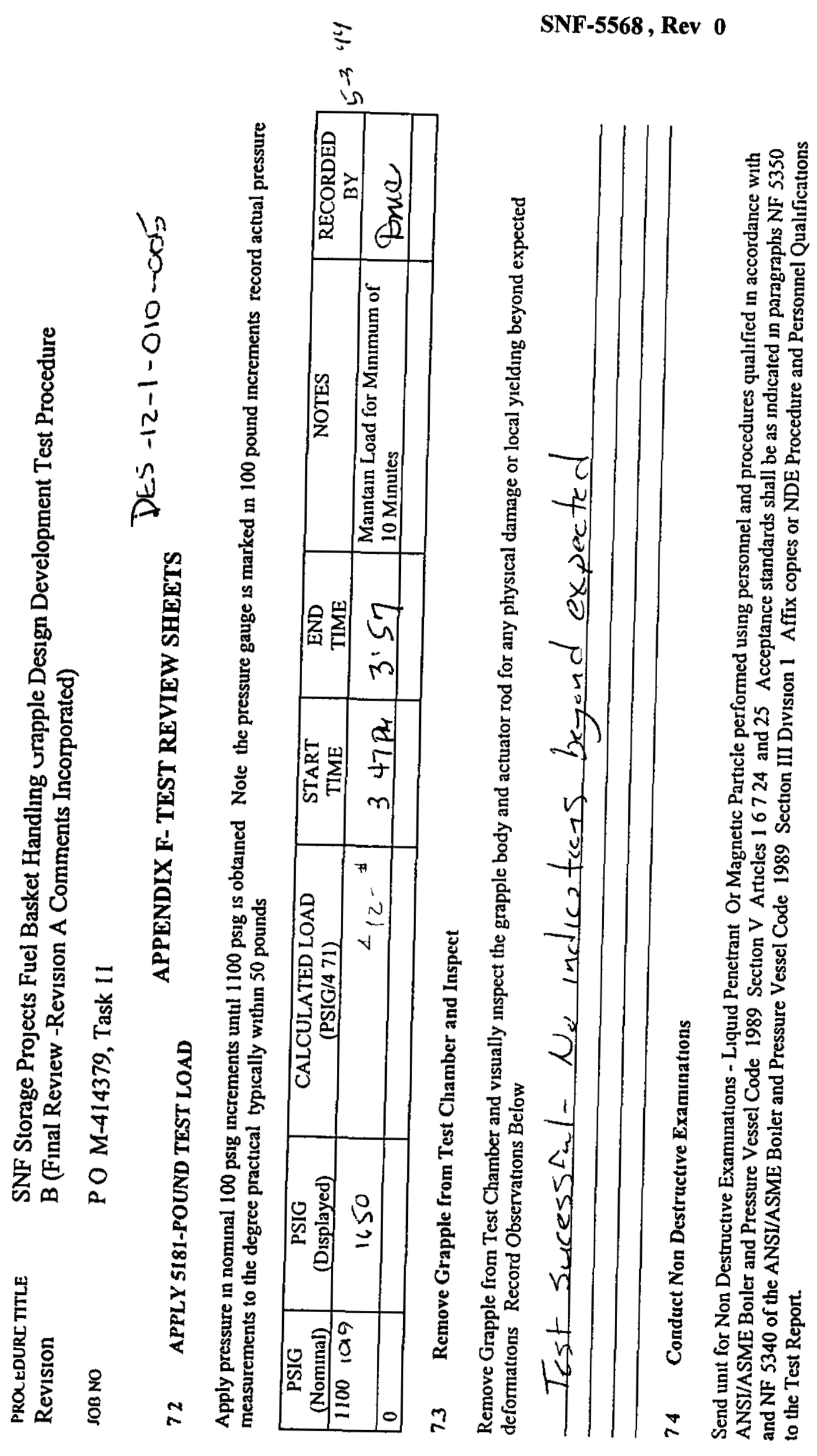

is 


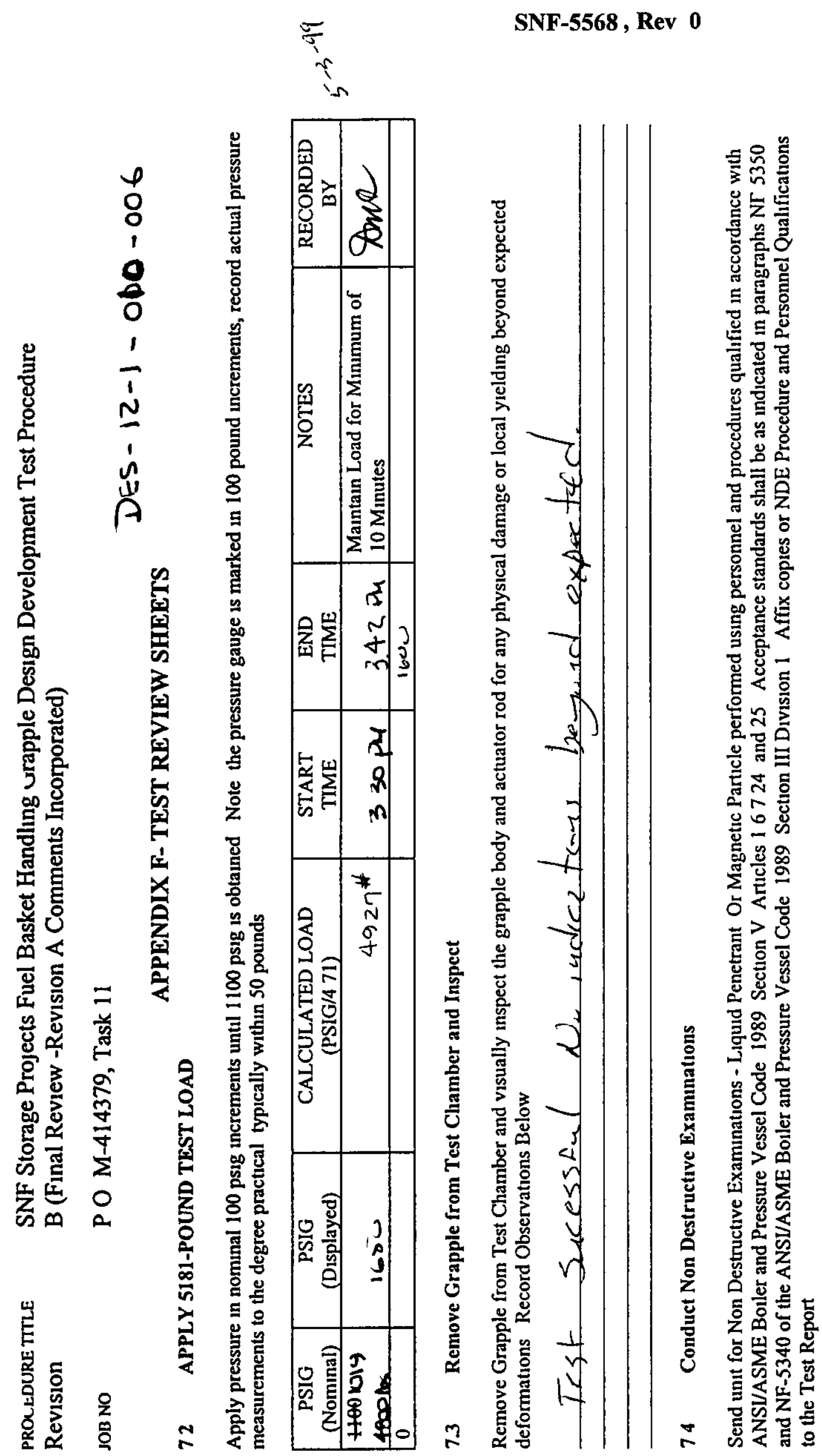




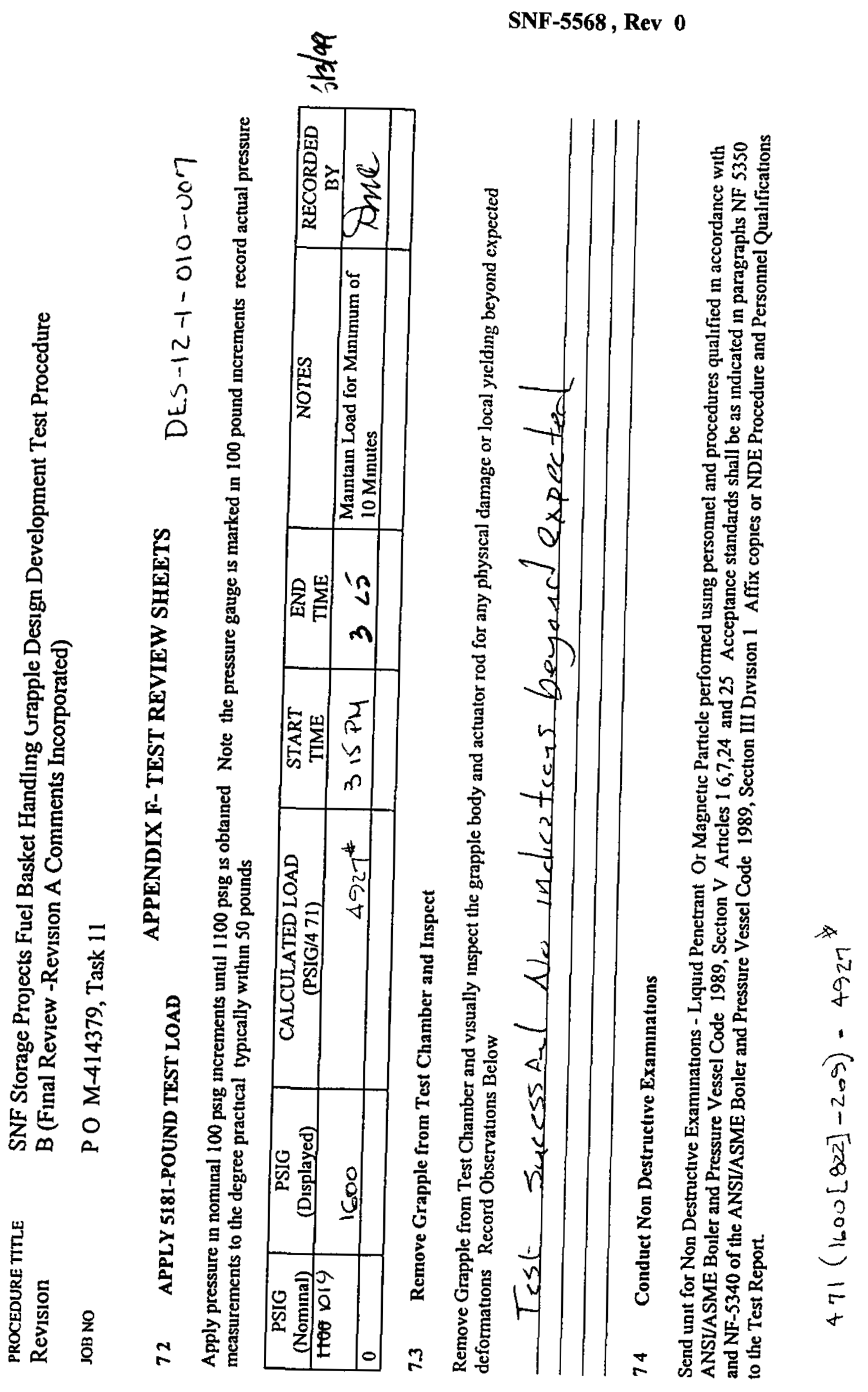


SNF-5568, Rev 0

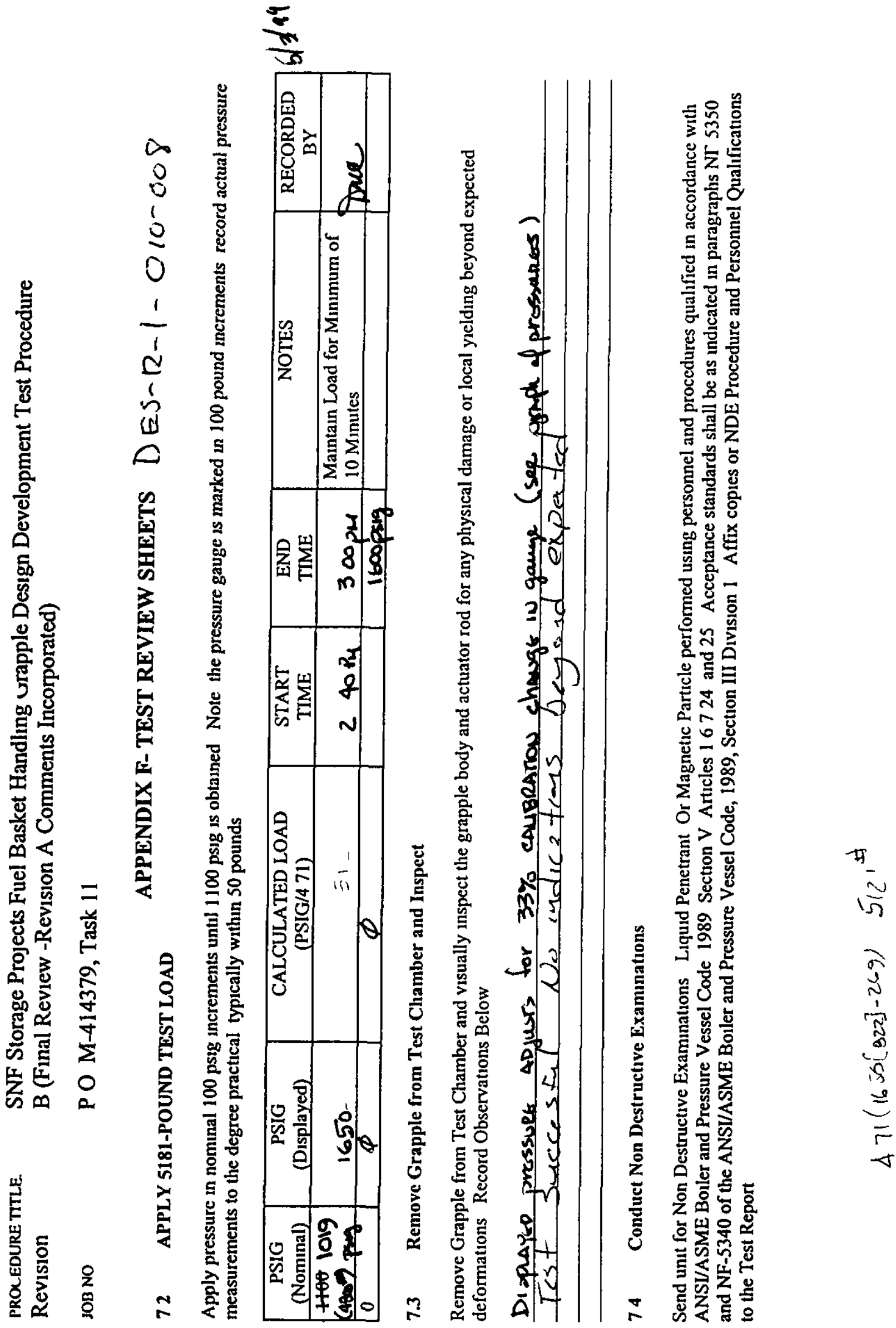

N 


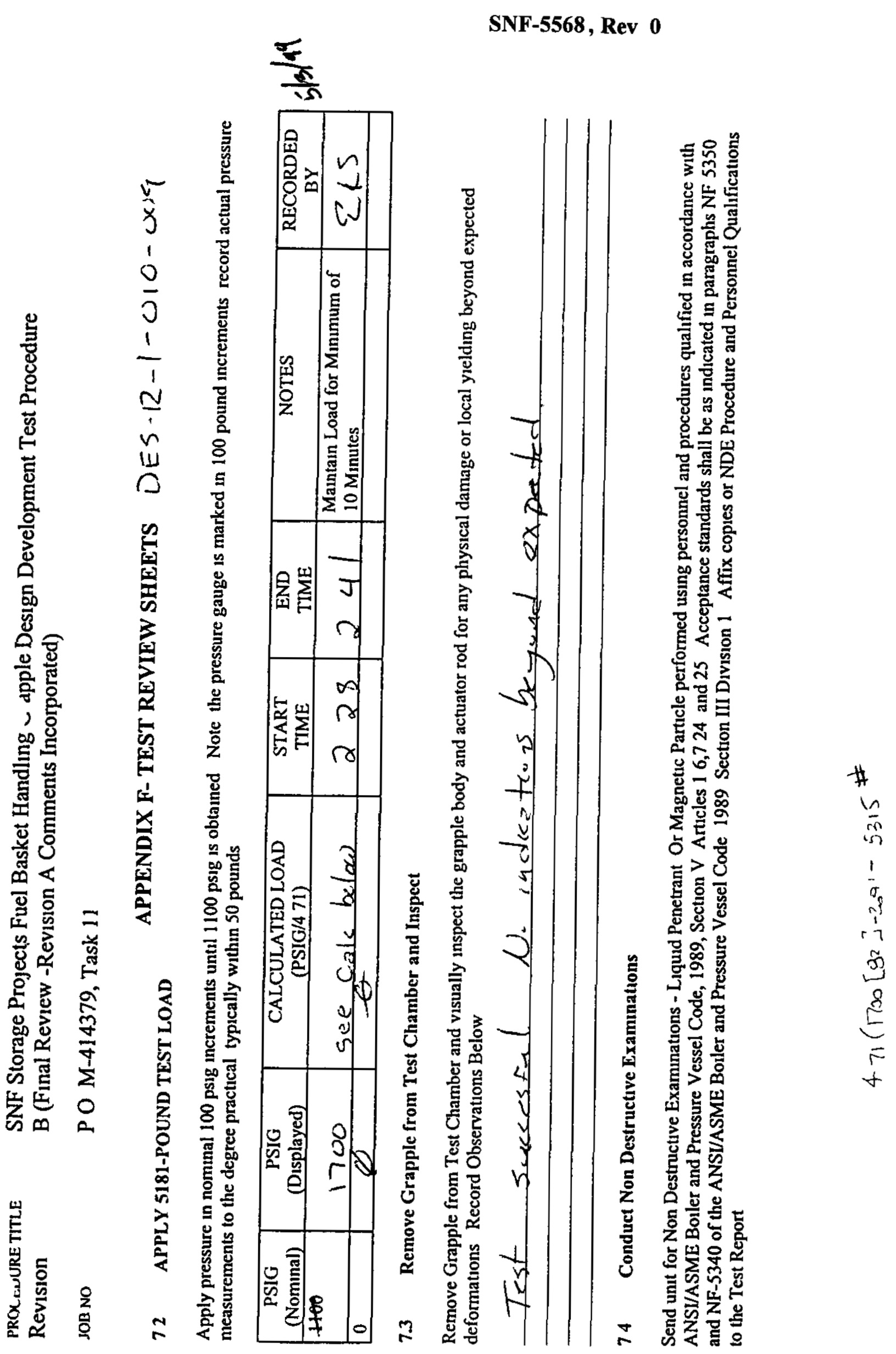




\section{Rev 0 \\ SNF-5568}

Appendix B

Ashcroft Pressure Gauge Calibration

Serıal Number Q 8451 
SNF-5568, Rev 0

Ashcroft Calbration Data TAG NO BEL99 251 Expires 5/5/2000

Reference Pressure Ashcroft Displayed

$1999629 \quad 1400$

3999188

$5999123 \quad 4450$

$7999107-6000$

9998968

Pressure As Found $=1797+775$ (Actual Pressure) or

Actual Pressure $=($ As Found Pressure +1797$) / 775$

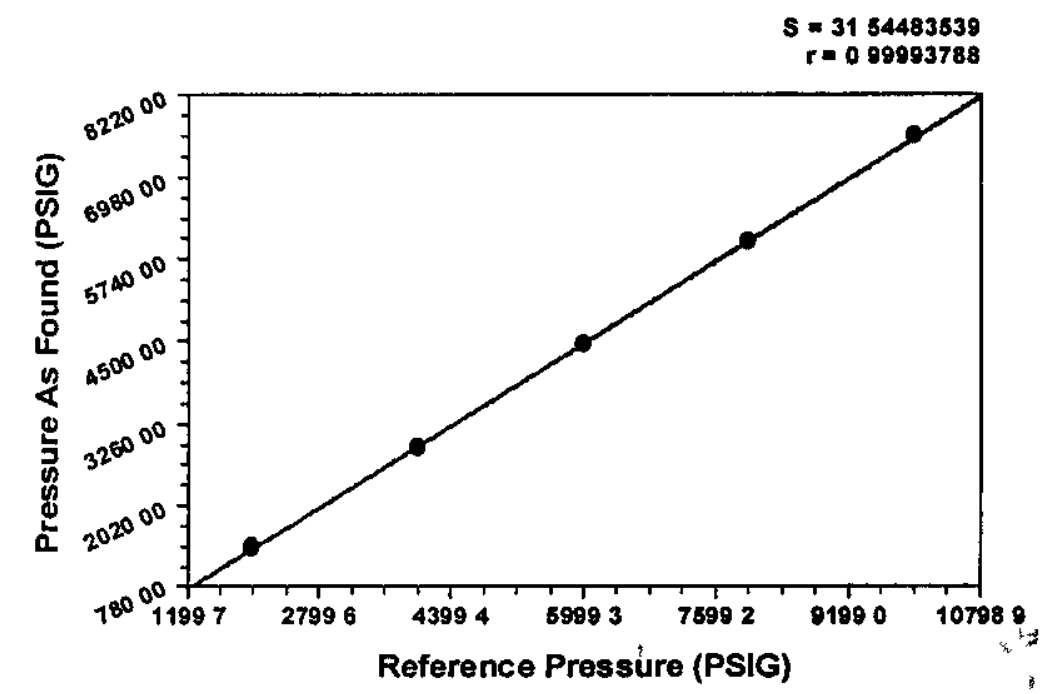

Test Load = Actual Pressure Area of Cylinder Where Area of Cylinder $=471$ Square Inches

Test Load $=(($ Ashcroft Pressure +179 7)/ 775) 471

\begin{tabular}{|crrr} 
Ashcroft Pressure & Actual Pressure & \multicolumn{3}{c}{ Test Load } & Overload \\
& 236090 & 1111985 & 3474954 \\
1650 & 242542 & 1142373 & 3569914 \\
1700 & 236090 & 1111985 & 3474954 \\
1650 & 236090 & 1111985 & 3474954 \\
1650 & 236090 & 1111985 & 3474954 \\
1650 & 229639 & 1081598 & 3379995 \\
1600 & 236090 & 1111985 & 3474954 \\
1650 & 242542 & 1142373 & 3569914 \\
1700 & 385381 & 1815143 & 5672321 \\
2807 & & &
\end{tabular}




\section{SNF-5568, Rev 0 \\ Belhaven Calibration Data Sheet Reoortumber

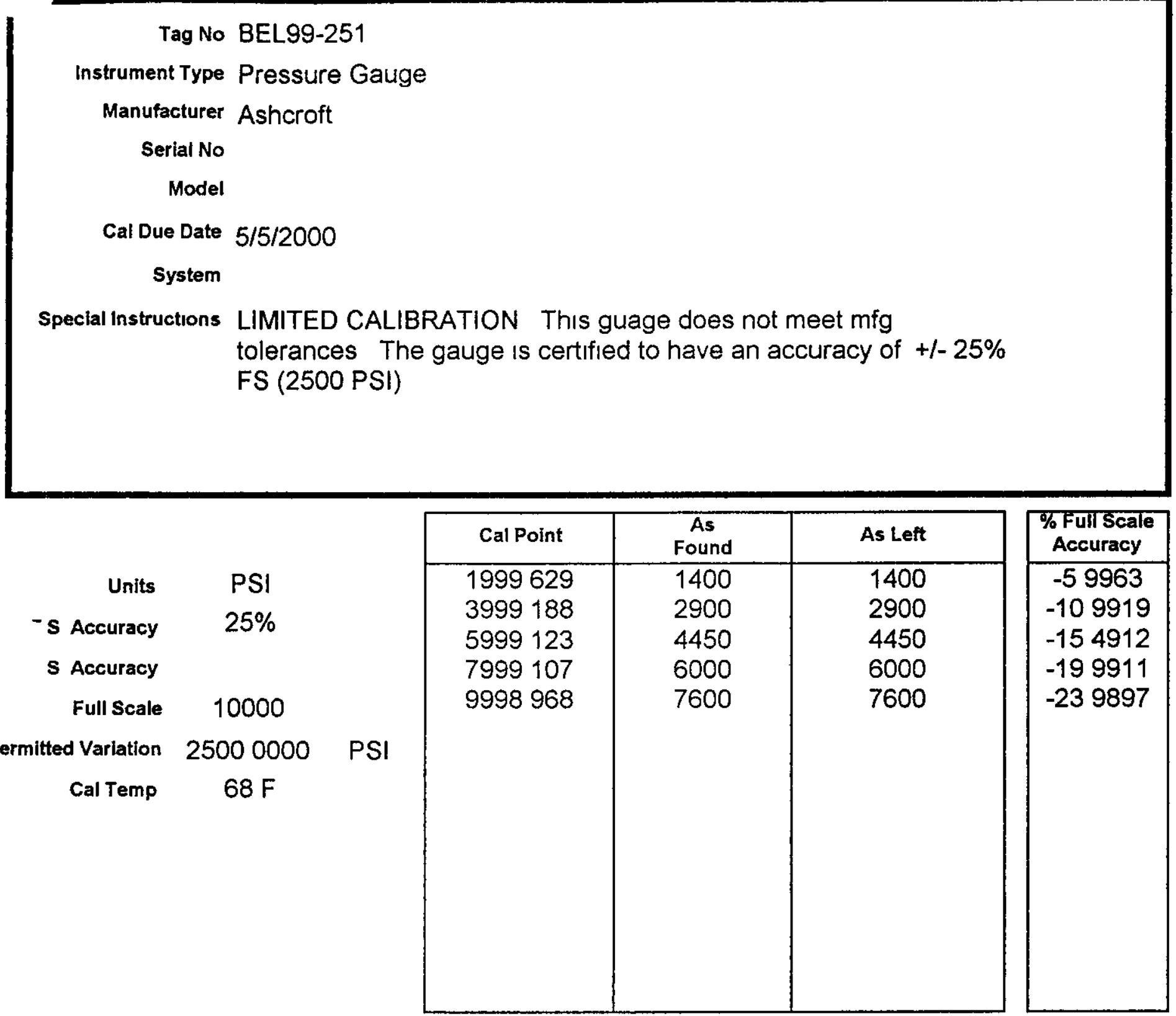

Test Equipment Ametek Deadweight Tester S/N 16132

Calibration Performed By

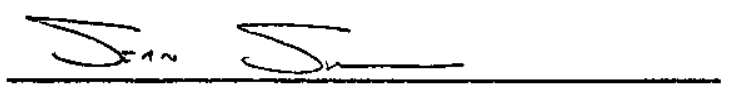

Date

$5-5-1119$ 


\section{Internal Memo}

To Dick Nelson, QA

From Eric Straalsund, Engineering

Subject Ashcroft Pressure Gauge Calibration

Date $\quad 5 / 22 / 98$

On 5/21/98 I sent the Ashcroft Pressure Gauge Serial \# Q-8451 to Bellhaven Instruments for it s annual calibration The Gauge recelved a LIMITED' calıbration as it was reading approximately $25 \%$ lower than expected values

Bellhaven provided MCE Engineering with the calibration curve and I have in turn plotted the data and calculated the best fit linear equation Copies of the calibration data and best fit equation are provided with this memo

For the upcoming Grapple Load Test (QA Class General ServIce), I propose using the Ashcroft Gauge and normalizing the resultant data with the calibration data

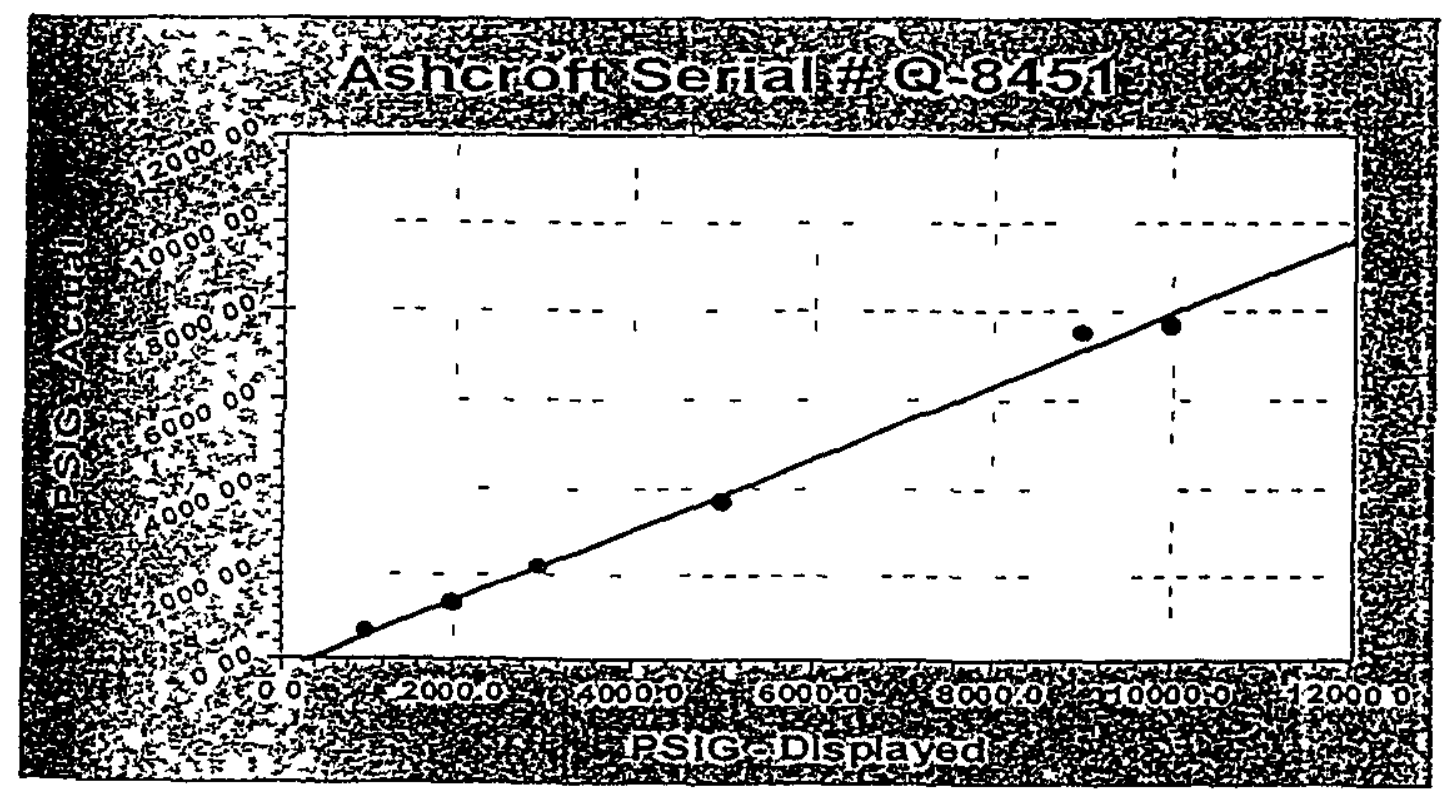

Linear Fit $y=a+b x$

Coefficient Data

$a=-26904762$

$b=082214286$

Desired Test Pressure is 1100 PSI Solve for Display Pressure from above Inearf " equation

$1100=26904+(822) \times$ or $X=1665$ Lbs 


\section{Belhave.d}

SNF-5568 CAEIBRATION DATA SHEET

Tag No

CAL98 95

DS Number

BEL98-160

Instrument Type Pressure Gauge 0 10K psi

Serial No Q-8451

Manufacturer

Asheroft

Model 0 10K

Tolerances

$35 \%$

Manufacturer QData Only

Callbration Due Date $\quad 5 / 21 / 99$

System

Special Instructions

\begin{tabular}{|c|c|c|c|c|c|}
\hline $\begin{array}{l}\text { Proc Step } \\
\text { No }\end{array}$ & $\begin{array}{l}\text { Function } \\
\text { Tested }\end{array}$ & $\begin{array}{l}\text { Required } \\
\text { Values } \\
\text { PSI }\end{array}$ & $\begin{array}{l}\text { As } \\
\text { Found } \\
\text { PSI }\end{array}$ & $\begin{array}{c}\text { As Left } \\
\text { PSI }\end{array}$ & $\begin{array}{l}\% \text { Out of } \\
\text { Tol }\end{array}$ \\
\hline & & $\begin{array}{l}1000 \mathrm{psi} \\
2000 \mathrm{psi} \\
3000 \mathrm{psi} \\
5000 \mathrm{psi} \\
9000 \mathrm{psi} \\
10000 \mathrm{psi}\end{array}$ & $\begin{array}{l}550 \text { psi } \\
1350 \text { pst } \\
2150 \text { psi } \\
3700 \text { psi } \\
7500 \text { psi } \\
7700 \text { psi }\end{array}$ & $\begin{array}{l}650 \mathrm{psi} \\
1350 \mathrm{psi} \\
2150 \mathrm{psi} \\
3700 \mathrm{psi} \\
7500 \mathrm{psi} \\
7700 \mathrm{psi}\end{array}$ & $\begin{array}{l}-3500 \% \\
-3250 \% \\
-2833 \% \\
-2600 \% \\
-1667 \% \\
-2300 \%\end{array}$ \\
\hline
\end{tabular}

Test Equipment Transcat Digital Pressure Gauge, S/N 590765, Cal Due Date 7/23/98 TAR of Gauge 25\% Full Scale (10K psI)

Ametek Dead Weıght Tester, S/N 16132, Cal Due Date 1/22/99

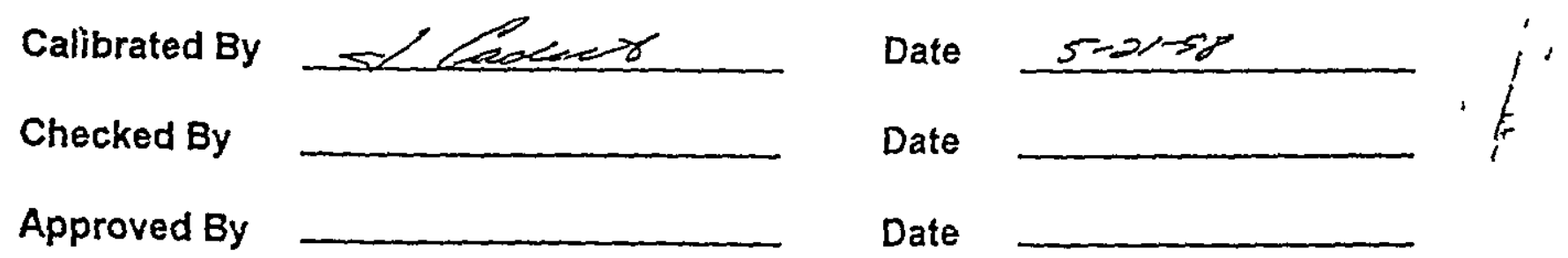


SNF-5568, Rev 0

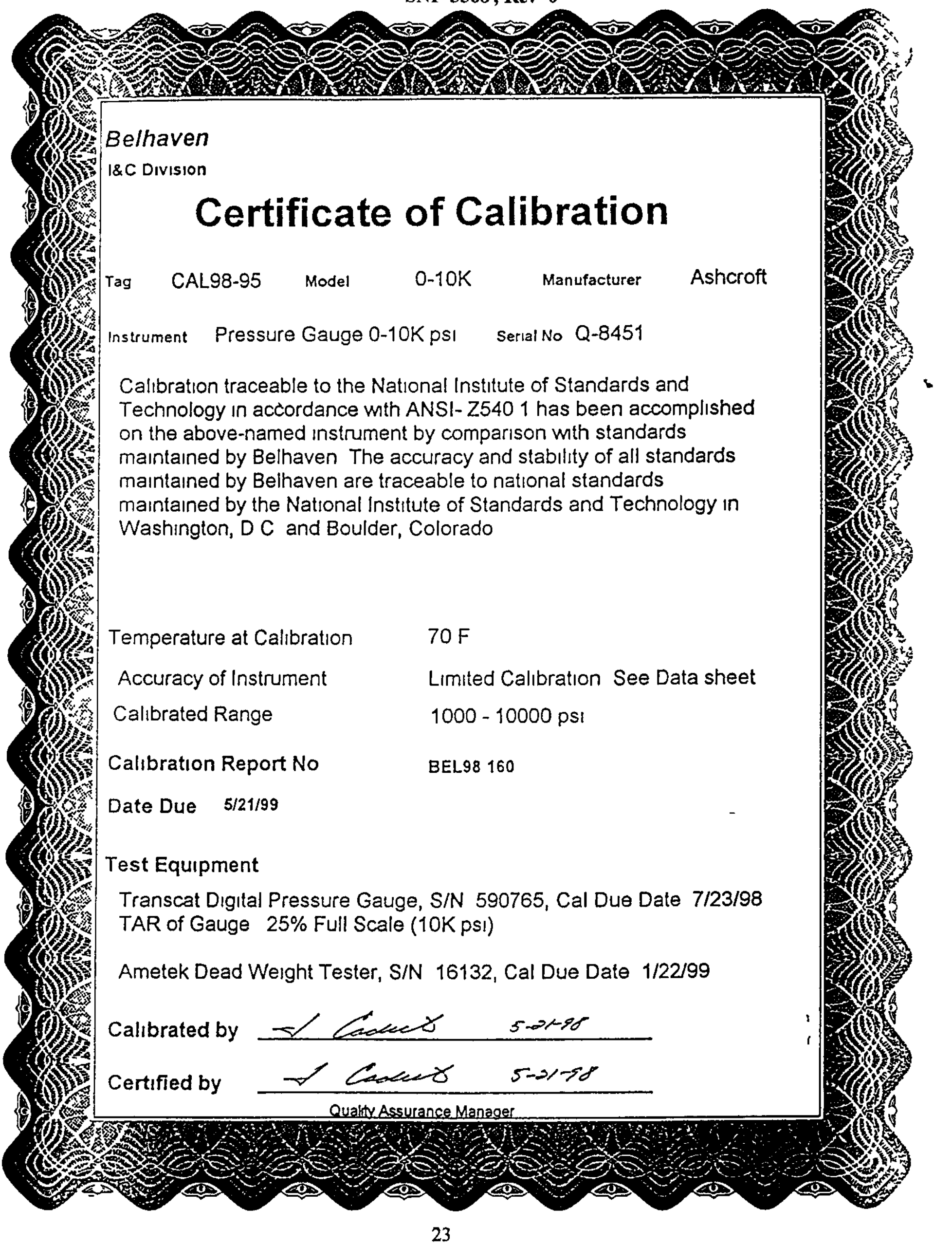


SNF-5568, Rev 0

Appendix C

Lıquid Penetrant Examınatıon Reports 
SNF-5568, Rev 0

Inspection Service, Inc

430 W Deschutes

Kennewick, Wa. 99336

\section{Liquid Penetrant}

Examination Report

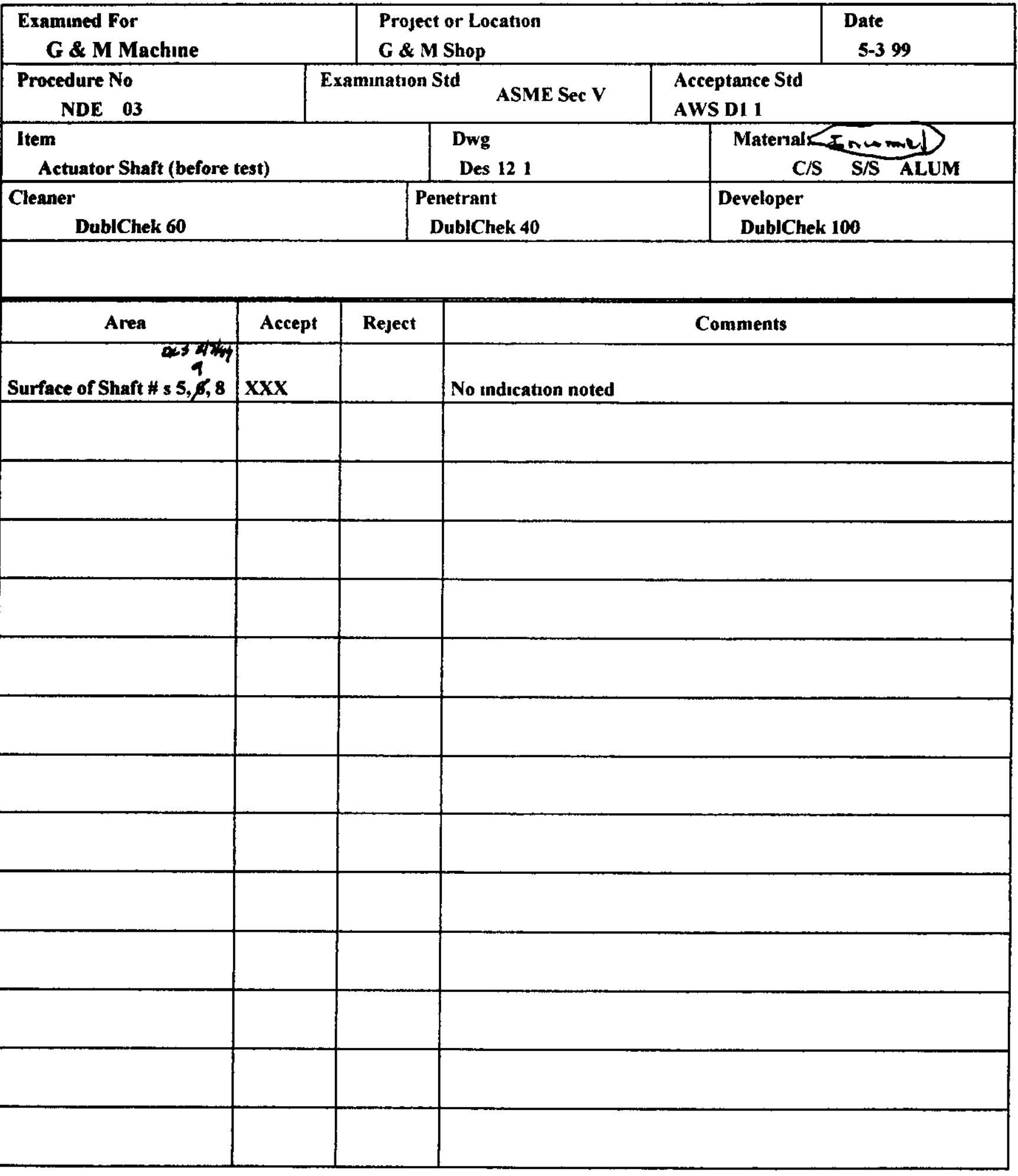

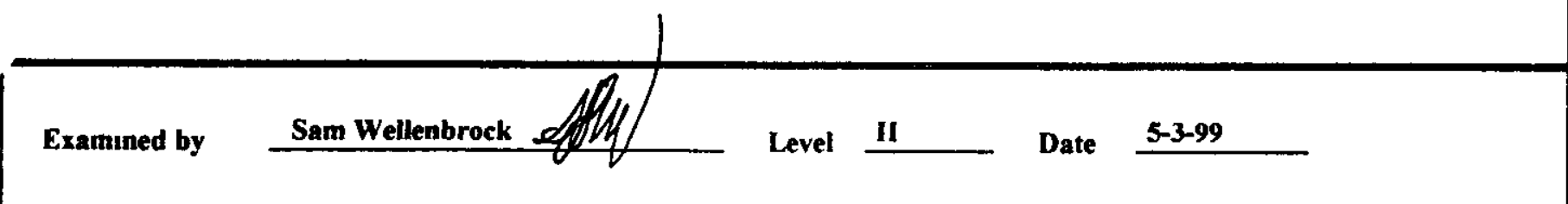


Inspection Service, Inc 430 W Deschutes

Kennewick Wa 99336

\section{Liquid Penctiant}

Examination Report

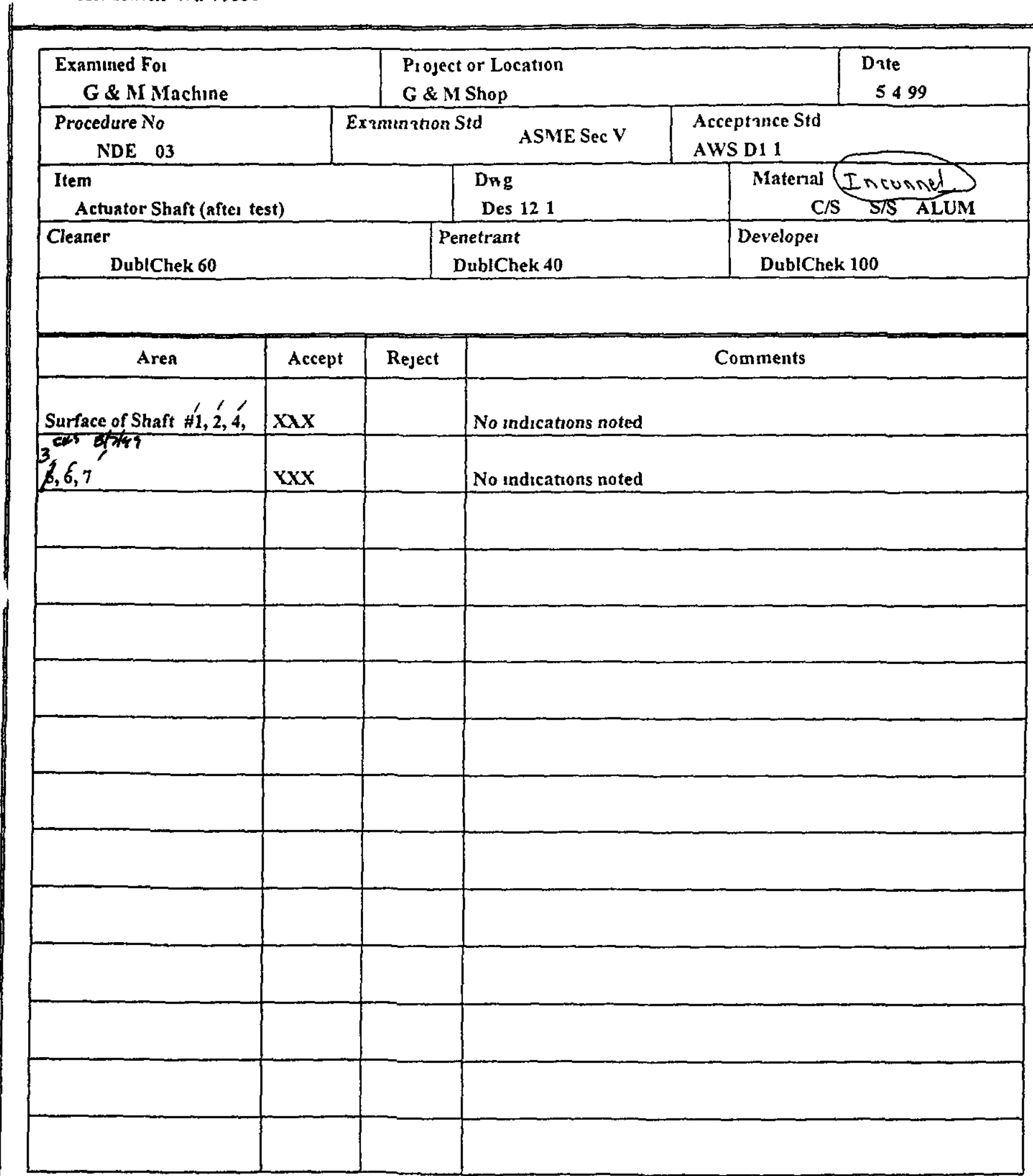

Examined bs 